\title{
THE EFFECTIVENESS OF ICE BREAKING TO INCREASE STUDENTS' MOTIVATION IN LEARNING ENGLISH
}

\author{
MOHAMMAD SOFYAN ADI PRANATA \\ RISKA AYU SUSANTI \\ QOMARIATUL JANNAH \\ Universitas Nurul Jadid, Paiton, Probolinggo \\ Sofy4ninho17@gmail.com
}

\begin{abstract}
This study was generally attempted to find the effect of ice breaking to increase students' motivation in English learning at the first grade of SMP Nurul Jadid. This research used pre-experimental design by using one shot case study pre-test and post-test. Before the treatment, the researcher gave the pre-test in one class. Moreover, the researcher taught English by using ice breaking in the experimental class. The last, the researcher conducted the post-test to know whether an ice breaking was effective for teaching English in experimental class. Based on the data analysis, the data t-test (2.77) was higher than t-table value (2.042). The result analyzing showed that there was significant difference on the students' motivation taught by using ice breaker. The students' mean score of the pre-test of the experiment class was 60 . Then, in the post-test, the mean score of experiment class was 66.1. Therefore, hypothesis $\mathrm{H}_{0}$ was rejected and $\mathrm{H}_{1}$ was accepted. It concluded that ice breaking was effective in teaching English learning toward the students' motivation for the first grade of SMP Nurul Jadid. Thus, this research make students be enjoy, be active, energize, feeling happiness, interactive in the classroom, stay in the class during learning process, and focus on the material.
\end{abstract}

Key Words : Ice breaking, Students' Motivation, First Grades of SMP Nurul Jadid

\section{INTRODUCTION}

Motivation is needed in students' developments through learning process, whether the students have motivation or not, it influenced their abilities. In teaching learning process, the teacher should be more attention to the students' motivation because motivation can influence both the teacher and the students. Moreover, students' motivation can be influenced by anything. It can be from the students themselves or from the environment; friends, family, and teacher who has important role in improving students' motivation in teaching and learning process.

In learning process, having motivation to learn is needed because it can determine whether a student has willingness to study or not. Motivation in learning is a motive that leads to the goal of learning process. Motivation in learning can be seen from students' behaviors and characteristics dealt with willingness, attention, concentration, and diligence. Students who have high motivation in learning will show willingness, attention and concentration to the study or learning activity. From another point of views, students who 
have low motivation will show unwillingness, be easy to feel bored and try to avoid the learning activity. Therefore, to make the students have motivation in learning, the teacher has to prepare some techniques that can improve the students' motivation by seeing things that can influence their motivation. There are several things which can be used to improve students' motivation such as; giving reward and praise for their good jobs.

Motivation was an energy change in someone's person characterized by the onset of effective (feelings) and reactions to achieve goals. Because someone had a certain purpose of its activities, then someone had strong motivation to achieve it with all the effort he could do to achieve (Diamarah, 2011). In English Foreign Language (EFL) contexts where motivation to learn English is driven mainly from external sources and exposure to English outside the classroom is somewhat limited, (Al shlowiy, 2014). According to (Urhahne, 2015), teachers can play an important role in enhancing or undermining students' motivation. This research is aimed at investigating student's motivation in SMP Nurul Jadid by using ice breaking.

Based on the researcher's observation on April 2021, there were a lot of students at the first grade of SMP Nurul Jadid who had low motivation to learning English. It could be seen when the students felt bored and sleepy in the class. The researcher thought that it is necessary to apply the technique in order to make the students feel motivated in learning English. Ice breaking technique is chosen to solve the problem because ice breaking is one of the techniques which is effective to increase students'motivation. According to Said (2010). Ice breaking was a game or activity that serves to change the freezing atmosphere in the group.

Ice Breaking in learning can be interpreted as a problem solver in students' mental or physical coldness. Ice Breaking was used to create an atmosphere of learning from passive to active, from rigid to motion (familiar) and from saturation to carefree (Sunarto, 2012). According to Flanigan (2011), accomplishing ice breaking strategy in class keeps students in a good mood in the learning process. Ice breaking in learning English could be done when opening a lesson, pausing during the delivery of material and when closing learning. Therefore, ice breaking is much needed in order to make the teaching learning process running well, interesting, and the students keeping concentrate to the lesson.

Motivation and ice breaking had relation because ice breaking assists the teacher to show enthusiasm about the content area and learning, and about the students themselves. One way to do this was to make a link with prerequisite knowledge and relate the content to what a student was familiar with. Theoretically, it can be concluded that ice breaking was interest 
technique which effective to motivated students in learning English. Thus, the researchers was interested in conducting pre-experimental research with the title "The Effectiveness of Ice Breaking To Increase Students' Motivation In Learning English At The First Grade Of Smp Nurul Jadid".

\section{Method}

This research was a Pre- Experimental design. Pre-experimental design involved one class as an experimental class. Arikunto in As'ad (2013) recited that the nature of the research was pre-experimental using "pre-test and post-test on group design. In this design, the observation was done twice before and after treatment. Observation made before treatment called pre-test and observation made after treatment called post-test.

The design can be presented as follows:

Tabel 1.1

\begin{tabular}{|lccc|}
\multicolumn{4}{c|}{ Research design } \\
\hline Group & Pre-test & Treatment & Post-test \\
\hline Experiment & 0 & $X$ & 0 \\
\hline
\end{tabular}

(Gay, $1981: 225)$

$\mathrm{X}$ : Treatment( using ice breaking)

$\mathrm{O}$ : The ability of experiment class after given treatment.

The sample was taken using purposive sampling. The researcher chooses class VII A as sample the number of the students were 32 students. Researcher was chose the sample because it was the first grade to learn English which usually students feel that English is boring and difficult at the first time they learn it. That was the researcher's reason to use ice breaking in teaching English to give a good impression to students in learning English that it is a fun and easy subject and it can motivate them in learning English.

Sugiyono (2010) stated research instrument was a tool used to measure and collect data in research so it was easier to be processed. The function of this research instrument was to get data information concerning execution of the study. In order to get data the research used instrument. For obtained data in this research used kinds of instruments namely tests learning motivation student questionnaire responses with Ice Breaking techniques and documentation. Questionnaire sheets were used to obtain data on learning motivation Student science. The questionnaire contains a collection of statements give to students for know the 
motivation to learn the statements given to students to know students' motivation in learning using techniques ice breaking learning. Documentation was a medium to obtain a visualization picture regarding student activities during the learning process takes place. Documentation in the form of student work during the activity and photos of activities done during learning by using camera media. Documentation done to see the notes made in research.

In analyzing the data, the researcher used SPSS 17.0. The data found in this research was compared by T-test to to significant differences between the score of pre-test and posttest. In the other hand, the researcher classified the students' level score motivation and standard deviation.

\section{FINDINGS AND DISCUSSION}

Finding

The findings of this research were based on the results of the data analysis. The data analysis was used to collect data. The students' motivation in learning English consisted of pre-test and post-test. The pre-test was given to know the students' motivation in learning English before giving treatment, and the post-test was given to know the increasing of the students' motivation in learning English after giving the treatment.

\section{The Classification of Students' Pre-test and post-test}

The questionnaire consisted of 20 items, each items provided with four alternatives of response result categories namely: strong agree, agree, and disagree. In data analysis, the researcher gave five classification components of students' motivation. They were less, low, enough, good, very good. The students' motivation levels were classified into some criteria as follow:

\section{Table 1.2}

The Frequency Distribution and Percentage of Students' Pre-test and Post-test score.

\begin{tabular}{|c|c|c|c|c|c|c|}
\hline \multirow{2}{*}{ No. } & Motivation & Range & \multicolumn{2}{|c|}{ Pre-test } & \multicolumn{2}{c|}{ Post-test } \\
\cline { 4 - 7 } & $\begin{array}{c}\text { Category } \\
\text { Range Score }\end{array}$ & & $\mathrm{F}$ & $\mathrm{P}(\%)$ & $\mathrm{F}$ & $\mathrm{P}(\%)$ \\
\hline 1. & Less & $1-16$ & 0 & 0 & 0 & 0 \\
\hline
\end{tabular}


VOL. 03 NO. 01, JUNE 2021

\begin{tabular}{|c|c|c|c|c|c|c|}
\hline 2. & Low & $17-32$ & 25 & 78.1 & 0 & 0 \\
\hline 3. & Enough & $33-48$ & 0 & 0 & 0 & 0 \\
\hline 4. & Good & $49-65$ & 7 & 21.9 & 16 & 50.0 \\
\hline 5. & Very good & $66-82$ & 0 & 0 & 16 & 50.0 \\
\hline \multicolumn{2}{r|}{} & & 32 & 100 & 32 & 100 \\
\hline
\end{tabular}

The table above shows that from the 32 students who followed the pre-test; sixteen students $(78.1 \%)$ were in low category, seven students $(21.9 \%)$ were in good category, while in post-test; sixteen students $(50.0 \%)$ were in good category, sixteen students $(50.0 \%)$ were in very good category. It means that the score and the percentages of the score in post-test are better than in the pre-test.

\section{Mean Score and Standard Deviation}

The mean score and the standard deviation of the pre-test and the post-test can be shown in the following table:

Table 1.3

Total Mean Score Standard Deviation of the Students in Pre-test and Post-test score.

\begin{tabular}{|l|l|l|l|l|}
\hline \multirow{2}{*}{ Class } & \multicolumn{2}{|l|}{ Pre-test } & \multicolumn{2}{l|}{ Post-test } \\
\cline { 2 - 5 } Experimental & Mean & Standard & Mean & Standard \\
& Score & Deviation & Score & Deviation \\
\cline { 2 - 5 } & 60 & 10.6 & 66.1 & 50.00 \\
\hline
\end{tabular}

The table above shows that, the mean and the standard deviation of pre-test and posttest score.

\section{Test of Significance Testing}

In order to know whether or not the mean score was statically different from two variables (pre-test and post-test)at the level of significant difference $(0,05)$ with the degree of freedom $(\mathrm{df})=\mathrm{N}-1$, where $\mathrm{N}=$ the total of the students (32). The following table shows the result of the t-test and t-table calculation: 
Table 1.4

The Result of T-test and T-table Calculation.

\begin{tabular}{|lll|}
\hline Variable & t-test & t-table \\
$\mathrm{X}_{1}-\mathrm{X}_{2}$ & 2.77 & $\mathbf{2 . 0 4 2}$ \\
\hline
\end{tabular}

The table above indicates that the value of the t-test was higher than the value of the t-table. It indicates that there was a significant difference between the result of the students' pre-test and post-test score.

\section{DISCUSSION}

The result of data analysis showed that using ice breaking has managed to motivate students in learning English. It could be seen from the effectiveness of ice breaking from the table above which showed that the t-test value was higher than $\mathrm{t}$ - table value. The $\mathrm{t}$-test was 2.77 and t-table was 2.042. It means that there was a significant increasing after treatment, so the students' motivation in learning English was effective by using ice breaking and also the percentage of pre-test there are 27 students who had low motivation, 7 students who had a good motivation. After giving treatment the percentage of students post-test, there are 16 students who got good, 16 students who got very good motivation. It means that there was an increasing of students' motivation using ice breaking in learning English at the first grade of SMP Nurul Jadid.

Therefore, there were some factors that influence the improvement of the students' motivation using ice breaking. The First this activity is very fun and makes learning compete to get the most motivation. Second, ice breaking could increase student confidence in learning thus makes students more active. Third, ice breaking could make the learning atmosphere be comfortable. According to Suryati (2014) ice breaking was one of the activities for divert the situation from astonishing, boring, sleepy be fun, excited, relaxed and not making it sleepy so the learning atmosphere could become more conducive to have a significant influence. So that it could make students were more active in learning process so that students' motivation in learning increased. 
VOL. 03 NO. 01, JUNE 2021

According to (Yeganehour, 2016) stated that using ice-breakers facilitates the communication among learners and is a good way for skipping from language barriers. As a communication strategy use of ice-breakers makes oral communication among students more easily and by suppressing the problem of linguistic knowledge of silent learners supports their attention and develops the communication among them. Thus, it is very need in learning process and increasing students' motivation especially in English learning.

The researcher concluded that the treatment by using ice breaker was very important to increase the students' motivation in learning English at the first grade in of SMP Nurul Jadid.

\section{CONCLUSION}

Based on the findings and the discussion, the researcher concluded that using ice breaking was effective to increase students' motivation in learning English at the first grade of SMP Nurul Jadid. It was proven from the result of students' motivation level which showed that there was a significant difference between students' pre-test and post-test and also the t-test value was higher than t-table value. So it could be stated that giving treatment by using ice breaker could help students to increase their motivation. 


\section{REFERENCES}

Al shlowiy, A. (2014). Lifting motivation level of English learners in Saudi Arabia. Arab World English Journal, 5(1), 129-136. Retrieved from http://www.awej.org/images/AllIssues/Volume5/Volume5Number1 March201411.pdf

Arikunto, Suharsimi.( 2013). Prosedur Penelitian. Jakarta: Rineka Cipta.

Djamarah, S. B. (2011) Definiton of motivation. Jakarta : Rineka Cipta.

Flanigan, E. (2011). The importance of ice braking and warm up activities in English class.

The International Journal of English Literature and Social Science (IJELS), (Online). 3(5), 6. Retrieved from http://www.journal.unpak.ac.id > index. php > Jet- $\mathrm{Li}>$ article >

Said, (2010). Definition of Ice Breaking. Yokyakarta: Andi Offset.

Sugiyono.(2010). Statistika untuk penelitian. Bandung,: Alfabeta

Sunarto, (2012). Definition of Ice Breaking . Surakarta: Cakrawala Media

Suryanti, "Ice Breaking influence towards Motovasi study chemistry students grade $\mathrm{X}$ Semester 2 at SMA Negeri 10 Yogyakarta school year 2013/2014" (Yogyakarta: Thesis UIN Sunan Kalijaga Yogyakarta, 2014). Loc. cit. h. 92-95

Urhahne, D. (2015). Teacher behavior as a mediator of the relationship between teacher judgment and students' motivation and emotion. Teaching and Teacher Education, 45, 73-82. http://dx.doi.org/10.1016/j.tate.2014.09.006

Yeganehour, P. (2016). Using Ice-Breaking in Improving Every Factor Which Considered in Testing Learning Speaking Ability. International Journal on New Trends in Education and Their Implications , 65. 